\title{
Seed quality enhancement through biopriming in common bean (Phaseolus vulgaris. L)
}

\author{
S. P. Monalisa ${ }^{1}$, J. K. Beura ${ }^{2}$, R. K. Tarai ${ }^{3 *}$, and M. Naik ${ }^{2}$ \\ 1 Department of Seed Science and Technology, Orissa University of Agriculture and Technology, Bhubaneswar- \\ 751003 (Orissa ), INDIA \\ 2 Department of Horticulture, College of Horticulture, University of Agriculture and Technology, Chiplima - \\ 768025 (Orissa), INDIA \\ * Corresponding Authors' E-mail : ranjanouat@gmail.com \\ Received: October 2, 2016; Revised received: April 9, 2017; Accepted: August 16, 2017
}

\begin{abstract}
An experiment on seed quality enhancement of common bean (Phaseolus vulgaris L.) var. S 9 (local) was conducted at the department of seed science and technology, OUAT, Bhubaneswar during 2013-14 by use of three biocontrol agents viz. Trichoderma viride, Trichoderma harzianum, Pseudomonas fluorescence. Seeds were bioprimed with the biocontrol agents at 40,50 and $60 \%$ concentration for 4,8,12 and 16 hours of soaking. Seeds were also hydro primed for 4,8,12 and 16 hours. Unprimed dry seed resulted in germination (69\%), shoot length (27.5 $\mathrm{cm})$, root length $(14 \mathrm{~cm})$, seedling dry weight (1.71g), SVI-I (2859.2), SVI-II (118.0) and speed of germination (5.8) while hydro primed seeds resulted in germination $(72 \%)$, shoot length $(31.9 \mathrm{~cm})$, root length $(15 \mathrm{~cm})$, seedling dry weight (1.80 g), SVI-1 (3375.9) SVI-II (129.8) and speed of germination (6.7). Trichoderma harzianum at $40 \%$ concentration and for 4 hours of soaking resulted enhancement of above quality parameter like $13.0 \%$ in germination, $21.1 \%$ in shoot length, $20.7 \%$ in root length, $31.6 \%$ in seedling dry weight, $36 \%$ in seedling vigour index-I, 48.1 $\%$ in seedling vigour index-II and $58.6 \%$ in speed of germination over unprimed seeds. Bio priming with $P$. fluorescence ( at $40 \%$ concentration and for 4 hour) closely followed and at par with best treatment with $11.6 \%, 18.2 \%$, $16.4 \%, 30.4 \%, 30.7 \%$ and $56.9 \%$ enhancement of above mentioned quality parameters, respectively.
\end{abstract}

Keywords: Biopriming, Trichoderma harzianum Trichoderma viride, ,Pseudomonas fluorescence, Unprimed seed

\section{INTRODUCTION}

Common bean (Phaseolus vulgaris L) is an important vegetable crop, which contains many nutritional benefits. The quality of seed alone is known to account for at least $10-15 \%$ increase in the productivity. However, lack of quality seed continues to be one of the greatest impediments to bridging the vast yield gap. Therefore, to approach the potentially realizable yield of a cultivar, production and distribution of quality seed is essential. Seed priming is a quality enhancement technique for rapid uniform germination of seeds and optimum plant stand in the field. This technique is often used as a seed invigoration treatment for improving germination and vigour in low vigour lots. Hence, it appears to reverse the detrimental effects of seed deterioration (Srinivasan et al., 2009).Biopriming is one of seed priming technique which was found to enhance seed quality parameters in common bean. It is recently used as an alternative method for controlling many seed and soil borne pathogens. Biological seed treatments provide an alternative to chemical control with additional benefits of induced diseases resistance, ecofriendly nature and sustainable diseases management. Trichoderma viride, Trichoderma harzi- anum, Pseudomonas fluorescence are different biocontrol agents frequently used for biopriming treatment.Several researchers have investigated the use of beneficial micro-organisms in the priming medium to control disease proliferation during priming itself (Warren and Bennet, 2000). Beneficial effects of biopriming on seed quality enhancement and yield of different pulse crops have been studied (Yadav et al.,2013). However, such information also found very limited in common bean(Fath El-babet al.,2013). Hence, an attempt has been made in this experiment to identify the most effective bio control agents and effective technique of bio priming and also to evaluate the effect of bio priming techniques on seed quality parameters in common bean which will ultimately help in enhancing its yield.

\section{MATERIALS AND METHODS}

An experiment on seed quality enhancement through biopriming in common bean (Phaseolus vulgaris. L) was conducted in the department of Seed science and Technology, at Orissa University of Agriculture and Technology, Bhubaneswar during 2013-14. Suspensions of three biocontrol agents viz. Trichoderma viride, Trichoderma harzianum and Pseudomonas flu- 
orescence were used in this experiment. These three biocontrol agents were collected from seed pathology laboratory of All India Coordinated Research Project on Seed Technology Research, OUAT, Bhubaneswar. Seeds of common bean variety S 9 were bioprimed with the three biocontrol agents at 40, 50 and $60 \%$ concentration for $4,8,12$ and 16 hours of soaking. Seeds were also hydro primed for 4,8,12 and 16 hours. The seeds were then shade dried followed by sun drying to bring down moisture content to original content. Two hundred seeds were used for each treatment in four replications $(50 \times 4)$. After treatments, the seeds were subjected to germination test for speed of germination, vigour index test based on seedling length and dry weight along with the control. Different treatments are $\mathrm{T}_{1}$-Control(Dry seed), $\mathrm{T}_{2}$ Hydropriming, $\mathrm{T}_{3-}$ Trichoderma viride $\mathrm{T}_{4}$ - Trichoderma harzianum, $\mathrm{T}_{5^{-}}$Pseudomonas fluorescence. Standard germination test was conducted by between paper towel method as described in the ISTA rules of seed testing (ISTA, 1999).Speed of germination was calculated on the basis of no. of seed germinated on each day from total seed used for germination test, until no further germination occurred and by using formula (Sen and Ghosh, 1999).Seedling length was measured and mean seedling length was expressed in centimeter and the mean dry weight of seedlings was recorded and expressed in grams.(AOSA, 1983).Bioprimed and hydro primed seeds were compared with unprimed seeds for their quality parameters viz, germination, seedling root and shoot length, seedling dry weight, seedling vigour index - I and II and speed of germination index based on sample size of 200 seeds for each test. The seed lot showing the higher seed vigour index is considered to be more vigorous.The formula for calculating SVI-I and SVI-II as described by (Abdul-Baki and Anderson, 1973) were :

Seedling Vigor index I $=$ Germination $\% \times$ Seedling length

Seedling Vigor index II $=$ Germination $\% \times$ Seedling dry weight

Duration of soaking was fixed at four hours which was found most suitable and also $40 \%$ concentration was fixed. The seeds were soaked in double the volume of suspension of biocontrol agents for 4 hours followed by drying to original moisture content. Then the seeds are subjected to germination test, vigour test, speed of germination test. The data were analyzed individually as per the standard analysis of variance (ANOVA) technique using Completely Randomized Design CRD.

\section{RESULTS AND DISCUSSION}

The experiment conducted to determine the optimum period of soaking in water/suspensions of biocontrol agents revealed that the benefit of priming was highest at four hours of soaking and seed quality parameters like germination, shoot length, root length, vigour index, and speed of germination index got reduced with increase in soaking period. Similarly the benefit of priming was highest at $40 \%$ concentration as compared to $50 \%$ and $60 \%$ concentration. Unprimed dry seed resulted $69 \%$ germination, $27.5 \mathrm{~cm}$ shoot length, $14 \mathrm{~cm}$ root length, $1.71 \mathrm{~g}$ seedling dry weight, (2859.2) SVI-I, (118.0) SVI-II and (5.8) speed of germination (Table $1)$. The figures for hydro primed seeds were $72 \%$, $31.9 \mathrm{~cm}, 15 \mathrm{~cm}, 1.80 \mathrm{~g}, 3375.9,129.8$ and 6.7 for the

Table 1. Standardization of Hour of Soaking of bio control agents and its effect on seed quality enhancement in Common Bean.

\begin{tabular}{|c|c|c|c|c|c|c|c|c|c|}
\hline $\begin{array}{l}\text { Biocontrol } \\
\text { Agent }\end{array}$ & $\begin{array}{l}\text { Hour of } \\
\text { soaking }\end{array}$ & $\begin{array}{l}\text { Germ. } \\
(\%)\end{array}$ & $\begin{array}{l}\text { Shoot } \\
\text { Length } \\
\text { (cm) }\end{array}$ & $\begin{array}{l}\text { Root } \\
\text { Length } \\
\text { (cm) }\end{array}$ & $\begin{array}{l}\text { Seedling } \\
\text { Length } \\
(\mathrm{cm})\end{array}$ & $\begin{array}{l}\text { Dry } \\
\text { Weight } \\
\text { (g) }\end{array}$ & SVI-1 & SVI-2 & $\begin{array}{l}\text { Speed of } \\
\text { germination }\end{array}$ \\
\hline Control & - & $69(56.17)$ & 27.5 & 14.0 & 41.5 & 1.71 & 2859.2 & 118.0 & 5.8 \\
\hline Hydropriming & $4 \mathrm{~h}$ & $72(58.06)$ & 31.9 & 15.0 & 46.9 & 1.80 & 3375.9 & 129.8 & 6.7 \\
\hline Hydropriming & $8 \mathrm{~h}$ & $70(56.95)$ & 31.1 & 13.5 & 44.6 & 1.73 & 3131.6 & 121.3 & 6.2 \\
\hline Hydropriming & $12 \mathrm{~h}$ & $67(54.64)$ & 29.8 & 12.5 & 42.3 & 1.68 & 2815.0 & 111.8 & 5.7 \\
\hline Hydropriming & $16 \mathrm{~h}$ & $32(34.14)$ & 25.9 & 11.6 & 37.5 & 1.59 & 1186.2 & 49.9 & 5.6 \\
\hline T. Viride & $4 \mathrm{~h}$ & $75(59.68)$ & 32.4 & 16.5 & 48.9 & 2.20 & 3639.2 & 164.0 & 8.5 \\
\hline T. Viride & $8 \mathrm{~h}$ & $70(56.48)$ & 31.0 & 15.8 & 46.8 & 1.89 & 3252.0 & 131.0 & 6.8 \\
\hline T. Viride & $12 \mathrm{~h}$ & $65(53.45)$ & 28.6 & 11.6 & 40.2 & 1.83 & 2593.6 & 117.9 & 6.2 \\
\hline T. Viride & $16 \mathrm{~h}$ & $59(50.19)$ & 28.2 & 12.0 & 40.2 & 1.64 & 2370.6 & 96.7 & 5.7 \\
\hline T. harzianum & $4 \mathrm{~h}$ & $78(61.68)$ & 33.3 & 16.9 & 50.2 & 2.25 & 3889.6 & 174.7 & 9.2 \\
\hline T. harzianum & $8 \mathrm{~h}$ & $70(56.64)$ & 30.2 & 13.2 & 43.4 & 1.92 & 3022.6 & 134.1 & 8.5 \\
\hline T. harzianum & $12 \mathrm{~h}$ & $67(54.64)$ & 22.7 & 11.5 & 34.2 & 1.64 & 2273.4 & 109.0 & 7.5 \\
\hline T. harzianum & $16 \mathrm{~h}$ & $31(33.52)$ & 18.1 & 11.1 & 29.2 & 1.62 & 893.8 & 49.5 & 6.2 \\
\hline P.fluorescense & $4 \mathrm{~h}$ & $77(61.01)$ & 32.5 & 16.3 & 48.8 & 2.23 & 3736.9 & 170.8 & 9.1 \\
\hline P.fluorescense & $8 \mathrm{~h}$ & $70(56.64)$ & 30.7 & 15.7 & 46.4 & 1.94 & 3235.7 & 135.1 & 7.3 \\
\hline P.fluorescense & $12 \mathrm{~h}$ & $55(47.87)$ & 30.0 & 14.8 & 44.8 & 1.90 & 2642.5 & 104.0 & 8.1 \\
\hline P.fluorescense & $16 \mathrm{~h}$ & $38(38.20)$ & 21.5 & 11.3 & 32.8 & 1.88 & 1244.6 & 74.5 & 6.6 \\
\hline SEM & - & 0.50 & 1.46 & 0.89 & 1.18 & 0.12 & 113.52 & 7.18 & 0.26 \\
\hline $\mathrm{CD}$ & - & 1.43 & 4.23 & 2.57 & 3.2 & 0.35 & 327.78 & 20.73 & 0.76 \\
\hline
\end{tabular}

*Mean of four replications, **figures in parentheses are angular transformed, Values;Germ. - Germination \%age, SVI-1- Seed- 
Table 2. Standardization of different Concentration of bio control agents and its effect on seed quality enhancement in common bean.

\begin{tabular}{lllllllll}
\hline $\begin{array}{l}\text { Biocontrol } \\
\text { agent }\end{array}$ & Concentration & $\begin{array}{l}\text { Germ. } \\
\text { (\%) }\end{array}$ & $\begin{array}{l}\text { Shoot } \\
\text { length }\end{array}$ & $\begin{array}{l}\text { Root } \\
\text { length }\end{array}$ & $\begin{array}{l}\text { Dry } \\
\text { weight }\end{array}$ & SVI-1 & SVI-2 & $\begin{array}{l}\text { Speed of } \\
\text { germination }\end{array}$ \\
\hline Control & - & $69(56.32)$ & 27.9 & 14.9 & 1.73 & 2958.3 & 119.9 & 5.8 \\
Hydropriming & - & $72(58.21)$ & 31.3 & 15.0 & 1.78 & 3344.6 & 128.8 & 6.7 \\
T. Viride & $40 \%$ & $75(60.00)$ & 34.0 & 17.7 & 2.21 & 3880.3 & 165.3 & 7.3 \\
T. Viride & $50 \%$ & $71(57.58)$ & 29.2 & 15.9 & 2.09 & 3209.2 & 148.9 & 6.5 \\
T. Viride & $60 \%$ & $73(58.54)$ & 28.5 & 11.7 & 1.80 & 2924.9 & 131.2 & 7.0 \\
T. harzianum & $40 \%$ & $79(62.73)$ & 34.6 & 18.1 & 2.26 & 4160.7 & 178.5 & 9.2 \\
T. harzianum & $50 \%$ & $73(58.70)$ & 31.6 & 13.1 & 2.15 & 3260.1 & 157.0 & 6.7 \\
T. harzianum & $60 \%$ & $72(57.90)$ & 30.9 & 13.1 & 1.89 & 2910.4 & 135.4 & 6.3 \\
P.fluorescense & $40 \%$ & $78(62.03)$ & 34.3 & 17.9 & 2.23 & 4071.2 & 174.1 & 9.2 \\
P.fluorescense & $50 \%$ & $75(59.68)$ & 30.0 & 15.0 & 2.05 & 3356.1 & 152.9 & 6.5 \\
P.fluorescense & $60 \%$ & $74(59.02)$ & 28.4 & 13.6 & 1.87 & 3086.7 & 137.5 & 7.3 \\
SEM & & 0.33 & 0.8 & 0.9 & 0.07 & 99.1 & 5.2 & 0.2 \\
CD & 0.95 & 2.4 & 2.5 & 0.20 & 286.0 & 14.9 & 0.7 \\
\hline
\end{tabular}

*Mean of four replications, **figures in parentheses are angular transformed values ,Germ. - Germination \%age, SVI-1- Seedling vigour index 1 , SVI-II- Seedling vigour index 2

above parameters. T. harzianum $40 \%$ concentration and 4 hour soaking (Table 1,2) resulted in 13.0, 21.1, 20.7, 31.6, 36.0, 48.1 and 58.6\%age enhancement of above quality parameters over unprimed seeds. $P$. fluorescence $(40 \%$, 4hour) closely followed and was at par with best treatment with $11.6,18.2,16.4,30.4,30.7$ and $56.9 \%$ enhancement of quality parameters, respectively. Soaking of seeds more than 8 hours had negative impact on seed quality with reduced values. The seeds of pulse crops like cowpea, beans are prone to imbibitions injury; hence a safe period of soaking in priming medium is necessary. Reports of earlier workers have indicated four to eight hours soaking suitable for the bean and related crops (Golezani et al.,2010, Shah et al., 2012, Fabunmi et al.,2012) found maximum priming hours was four hour for one variety and six hour for another under early moisture stress condition and concluded that varieties of same crop might require varied priming hours. But Golezani et al. (2010) could not find significant interaction of priming duration into cultivars of pinto bean where seven hours was optimum for all cultivars. Moosavi et al. (2012) suggested eight hour seed hydropriming of soybean seeds optimum for achieve maximum plant height, grain yield, oil content, dry weight and germination \%age.

Selection of a priming method is important in harnessing the benefits of priming; the best methodology may vary with crop species. (Nirmala and Umarani, 2008). Hydropriming for 12 hours and solid matrix priming for 24 hour was found to significantly increase seed quality and marketable yield of okra (Sharmaa et al., 2014) indicating that duration of soaking may vary with priming methods. Concentration of bioagents higher than $40 \%$ did not produce significantly higher results. From the study it was concluded that biopriming of bean seeds with $T$. harzianum or P. fluorescence $40 \%$ concentration for 4 hour can significantly enhance seed quality.
Biopriming is often found better than hydro priming and unprimed seed as it has added advantage of controlling seed and soil borne pathogens and plant growth promoting effects. Bioprimed seed showed higher germination and better plant growth as compared to control and combinations comprising Trichoderma with other bioagents showed better results in chickpea and rajma. (Yadav et al., 2013). Karthika and Vanangamudi (2013) found higher values of speed of germination, root length and shoot length, dry matter production and vigour index over control by biopriming of maize seeds with Azosphirillum (20\%) and Phosphobacteria (20\%) for 12 hour.

\section{Conclusion}

It can be concluded from the present investigation that farmers in the state are using low quality seeds which need to be treated before sowing for quality enhancement. Biopriming of seeds with Trichoderma harzianum and Pseudomonas fluorescence 40\% concentration for 4 hours enhance the seed quality parameters. Biopriming of seeds with Trichoderma harzianum for 4 hours of soaking gave better result in terms of germination $(78 \%)$, seedling length $(50.2 \mathrm{~cm})$, seedling dry weight (2.25 g), SVI-I (3889.6), SVI-II (174.7) and speed of germination index (9.2). Also using $40 \% \%$ concentration of Trichoderma harzianum resulted germination of $79 \%$, shoot length of $34.6 \mathrm{~cm}$, root length of $18.1 \mathrm{~cm}$, seedling dry weight of $2.26 \mathrm{~g}$, SVI-I of 4160.7 and SVI-II of 178.50 and speed of germination index of 9.2 in common bean variety S 9 . Hence, it can be inferred that Trichoderma harzianum at 4 hours of soaking and at $40 \%$ concentration was found best enhancing seed quality parameters in common bean.

\section{REFERENCES}

Abdul-Baki, A. A. and Anderson, J. G.(1973). Vigour deter- 
mination in soybean seeds by multiple criteria. Crop sci ., 13: 630-633.

A.O.S.A. (1983). (Association of Official Seed Analysis). Seed Vigour Testing Handbook, 32: 23-29.

Fabunmi ,T. O, Gbadamosi, B. K. and Adigbo, .S O. 2012. Seed hydro priming and early moisture stress impact on biomass production and grain yield of cowpea. International Journal of Applied Science and Technology 2 (10):112-122.

Fath, EL-bab, T. Sh and Riad ,S.R, El-Mohamedy.(2013) Biopriming seed treatment for suppressive root rot soil borne pathogens and improvement growth and yield of green bean (PhaseolusvulgarisL.). Journal of Applied Science Research 9(7):4378-4387.

Golezani, K, A. Jeddi, S. Naraollabzadeh and Moghaddam M. ( 2010 ). Influence of hydropriming duration on field performance of pinto bean (Phaseolus vulgaris L.). African Journal of Agriculture Research 5(9): 893-894.

ISTA. International seed testing association.(1999). Seed Science and Technology. 27: 1-33.

Karthika, C. and Vanangamudi,K.( 2013). Biopriming of maize hybrid $\mathrm{COH}(\mathrm{M}) 5$ seed with liquid biofertilizers for enhanced germination and vigour. African Journal of Agricultural Research 8(25):3310-3317.

Moosavi,S. S, Khanghah,D. H, Khanghah,M.A, Alaei,Y and Jafari ,M.(2012). A study on seed hydropriming effects on morphological traits and quanlitative and quantitative yield in soybeans under farm conditions. Life Science Journal 9(4):1546-1552.
Nirmala, K. and Umarani, R.(2008). Evaluation of seed priming methods to improve seed vigour of okra (Abelmoschusesculentus) and beetroot (Beta vulgaris). Seed Science and Technology 36:56-65.

Sen, S. and Ghosh N.(1999). Seed Science and Technology. Kalyani publishers, Ludhiana. pp.126

Shah H,, Jalwat T., Arif, M. and Miraj,G. (2012). Seed priming improves early seedling growth and nutrient uptake in mungbean. Journal of plant nutrition 35:805-816.

Sharmaa, A.D, Rathoreb, S.V. S, K. Srinivasan and Tyagia,R.K (2014). Comparison of various seed priming methods for seed germination, seedling vigour and fruit yield in okra (AbelmoschusesculentusL.Moench). ScientiaHorticulturae 165:75-81.

Srinivasan,K, Jain,S.K, S.Saxsena, Radhamani,J. and Manju, U.(2009). Seed priming and fortification. Seed Research Journal 37(1 \& 2):1-13

Warren, J.E. and Bennet,M.A.(2000).Biopriming tomato (LycopersiconeschlentumMill.) seeds for improvement of stand establishment. Advances and Applications in seed Biology. CAB Intl., Wallingtoford, U. K. 48-69.

Yadav, S.K., Dave,A., Sarkar,A.,Harikesh,B.S.and Sharma,B.K.(2013). Co-inoculated biopriming with Trichoderma, Pseudomonas and Rhizobium improves crop growth in CicerarietinumandPhaseolus vulgaris. International Journal of Agriculture, Environments and Biotechnology 6(2): 255-259. 